\title{
Planning for disposal of COVID-19 pandemic wastes in developing countries: a review of current challenges
}

\author{
Hassan El-Ramady • Eric C. Brevik (D) Heba Elbasiouny • Fathy Elbehiry • Megahed Amer • \\ Tamer Elsakhawy • Alaa El-Dein Omara $\cdot$ Ahmed A. Mosa • Ayman M. El-Ghamry $\cdot$ Neama Abdalla \\ Szilárd Rezes · Mai Elboraey • Ahmed Ezzat · Yahya Eid
}

Received: 31 March 2021 / Accepted: 30 July 2021 / Published online: 23 August 2021

(C) The Author(s), under exclusive licence to Springer Nature Switzerland AG 2021

\begin{abstract}
The health sector is critical to the wellbeing of any country, but developing countries have several obstacles that prevent them from providing adequate health care. This became an even larger concern after the COVID-19 outbreak left millions of people dead worldwide and generated huge amounts of infected or potentially infected wastes. The management and disposal of medical wastes during and post-COVID-19 represent a major challenge in all countries, but this challenge is particularly great for developing countries that do not have robust waste disposal infrastructure. The main problems in developing countries include inefficient treatment procedures, limited capacity of healthcare facilities, and
\end{abstract}

\section{Highlights}

- Developing countries suffer from COVID-19 biomedical wastes

- Effective management of COVID-wastes is a major challenge

- The best management practices need to be established for developing countries

- An integrated approach including environmental and medical aspects is needed

H. El-Ramady

Soil and Water Dept, Faculty of Agriculture, Kafrelsheikh

University, Kafr El-Sheikh 33516, Egypt

e-mail: hassan.elramady@agr.kfs.edu.eg

E. C. Brevik $(\square)$

College of Agricultural, Life, and Physical Sciences,

Southern Illinois University, Carbondale, IL, USA

e-mail: Eric.Brevik@siu.edu improper waste disposal procedures. The management of medical wastes in most developing countries was primitive prior to the pandemic. The improper treatment and disposal of these wastes in our current situation may further speed COVID-19 spread, creating a serious risk for workers in the medical and sanitation fields, patients, and all of society. Therefore, there is a critical need to discuss emerging challenges in handling, treating, and disposing of medical wastes in developing countries during and after the COVID-19 outbreak. There is a need to determine best disposal techniques given the conditions and limitations under which developing countries operate. Several open questions need to be investigated concerning this

\footnotetext{
H. Elbasiouny

Department of Environmental and Biological Sciences, Home Economy Faculty, Al-Azhar University,

Tanta 31732, Egypt

e-mail: hebaelbasiouny@azhar.edu.eg

F. Elbehiry

Central Laboratory of Environmental Studies, Kafrelsheikh University, Kafr El-Sheikh 33516, Egypt e-mail: fathyelbehiry@gmail.com

M. Amer

Soils Improvement Dept., Soils, Water and Environment Research Institute, Sakha Station, Agricultural Research Center, Kafr El-Sheikh 33717, Egypt

e-mail: megahedamer3@gmail.com

T. Elsakhawy · A. E.-D. Omara
} 
global issue, such as to what extent developing countries can control the expected environmental impacts of COVID-19, particularly those related to medical wastes? What are the projected management scenarios for medical wastes under the COVID-19 outbreak? And what are the major environmental risks posed by contaminated wastes related to COVID-19 treatment? Studies directed at the questions above, careful planning, the use of large capacity mobile recycling facilities, and following established guidelines for disposal of medical wastes should reduce risk of COVID-19 spread in developing countries.

Keywords Corona virus $\cdot \mathrm{SARS}-\mathrm{CoV}-2 \cdot$ Medical wastes $\cdot$ Waste disposal

\section{Introduction}

Several of types of wastes are generated by human activities, including agricultural, industrial, medical/healthcare (hereafter "healthcare"), electronic, municipal solid, radioactive, and food wastes (Ma et al., 2021). Some of these wastes, such as healthcare, radioactive, municipal, and electronic wastes, are or may be considered hazardous and can cause serious problems for human health; this can include transmission of infectious diseases with healthcare and municipal wastes (Steffan et al., 2018; Yazdani et al., 2020). The disposal of healthcare wastes, particularly items such as used face masks and gloves, is considered one of the biggest challenges facing urban municipalities and medical providers during

Agriculture Microbiology Department, Soil, Water and Environment Research Institute (SWERI), Agriculture Research Center, Sakha Agricultural Research Station, Kafr El-Sheikh 33717, Egypt e-mail: drelsakhawyg@gmail.com

A. E.-D. Omara

e-mail: calpsdean@siu.edu; alaa.omara@yahoo.com

A. A. Mosa - A. M. El-Ghamry

Soils Department, Faculty of Agriculture, Mansoura University, Mansoura 35516, Egypt

e-mail: ahmedmosa@mans.edu.eg; ahmed.kassem@agr.

kfs.edu.eg

\section{N. Abdalla}

Plant Biotechnology Dept, , Genetic Engineering \& Biotechnology Research Div, National Research Centre, Cairo 12622, Egypt

e-mail: neama_ncr@yahoo.com the COVID-19 pandemic (Ilyas et al., 2020; Manupati et al., 2021).

The severe acute respiratory syndrome coronavirus 2 (SARS-CoV-2) has attracted global attention because it causes coronavirus disease 2019 (COVID19) (Sangkham, 2020), which had over 178 million confirmed cases that caused more than 3.86 million deaths by 21 June, 2021 (WHO, 2021). The infectious wastes generated by the COVID-19 outbreak have created serious environmental and health concerns in many countries worldwide (Zand \& Heir, 2020) (Fig. 1). These wastes may be contaminated with blood, tissues, bodily fluids, organs, and sharp objects from treatment and includes swabs, diagnostics, and medical devices (Zhang et al., 2020a). Inadequate management of healthcare wastes may increase the spread of COVID-19, especially in developing countries where regulations governing waste disposal are not as robust as in developed nations (Zhang et al., 2020a). Most Asian developing countries (e.g., Bangladesh, Cambodia, India, Indonesia, Malaysia, Palestine, Philippines, Thailand, and Vietnam) have poor management of solid wastes that are often located in open landfills (Sangkham, 2020). Developing countries in Africa and other places may also suffer from improper waste disposal techniques, which may cause severe disease outbreaks and environmental problems (Sangkham, 2020).

Therefore, the purpose of this work is to advocate for preemptive planning to address the proper disposal of COVID-19 wastes generated in developing countries. We also explore whether there are links

S. Rezes · M. Elboraey

Division of Oto-Rhyno-Laryngology, Medical and Health

Science Center, Debrecen University, 4032 Debrecen,

Hungary

e-mail: rezes.szilard@med.unideb.hu

M. Elboraey

e-mail: ame.egypt@gmail.com; dr.maient@gmail.com

\section{A. Ezzat}

Horticulture Dept, Faculty of Agriculture, Kafrelsheikh University, Kafr El-Sheikh 33516, Egypt

Y. Eid

Poultry Dept, Faculty of Agriculture, Kafrelsheikh

University, Kafr El-Sheikh 33516, Egypt

e-mail: yahya.eid@agr.kfs.edu.eg 
between the disposal of healthcare wastes generated during the COVID-19 pandemic and COVID-19 transmission, and the expected environmental impacts of this waste disposal.

\section{Waste disposal and its management}

Wastes are substances that result from any human activity that produces unwanted or unusable material. The generation of wastes can be measured in kilograms per person per day and can be classified into three types, (1) solid, (2) liquid, and (3) gaseous. The management of wastes or waste disposal includes activities and actions from its initial generation to its final disposal, including the storage, collection, transport, processing, recycling or treatment, and disposal of wastes, together with monitoring and regulation of the waste management process (Ferronato \& Torretta, 2019). This management is primarily designed to convert the waste from hazardous or inert material into a form that does not threaten human health and the environment, or to contain the waste in a way such that it does not represent a threat (Wang \& Su, 2020). Several recent reports have addressed various types of wastes, their handling, and management (Table 1).

Wastes can be a significant resource when we can use them, for example, as organic nutrient sources to support agricultural production or as an energy source, or recycle them, but hazardous wastes need to be disposed of in a safe way. The production, handling, and management of wastes (particularly healthcare wastes) differ in developing countries compared to developed countries, as developing countries tend to have fewer regulations that oversee waste management (Fig. 2). In turn, these developing countries suffer adverse impacts to public health (Diaz et al., 2005; Elbehiry et al., 2020). Many studies have reported on the handling, treatment, and management of wastes in developing countries
Fig. 1 The environmental impacts of COVID-19 are an important global issue, particularly after the second wave. There are multiple problems caused by COVID-19, which includes disposal of several medical and healthcare wastes (mainly face masks and gloves) and direct or indirect links between wastes and the risks of COVID-19 transmission in different environments including soil and water

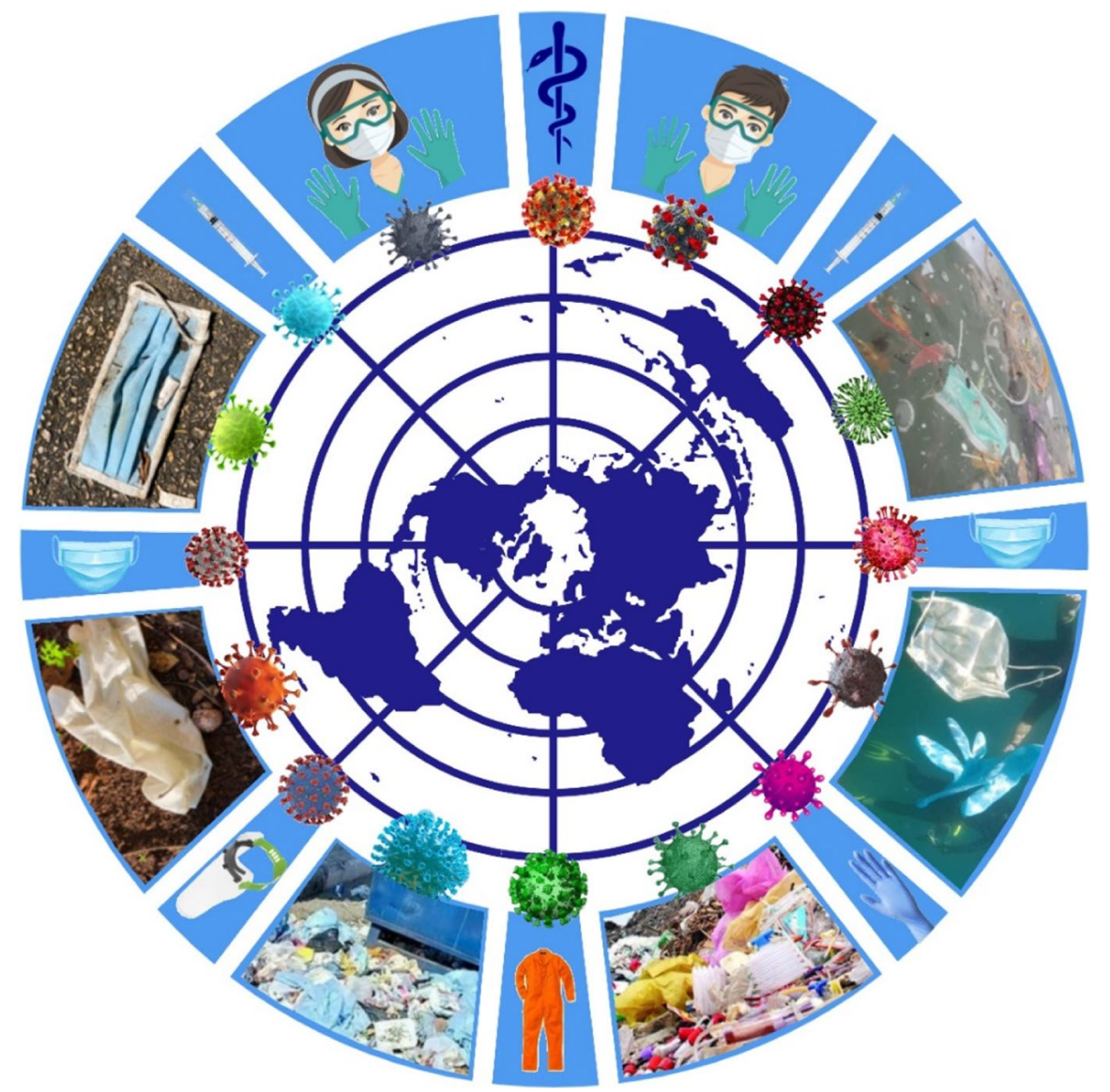


(Liang et al., 2021; Pandey et al., 2021; Wu et al., 2021). In general, developing countries are characterized by poor healthcare waste management and often employ improper waste disposal techniques (Manupati et al., 2021).

\section{Healthcare waste disposal techniques}

Medical sector wastes are potentially bio-hazardous and infectious. They are generated at a variety of healthcare facilities such as physician's offices, hospitals, medical laboratories, blood banks, and research facilities (Manupati et al., 2021). These wastes are considerable sources of risk of infection or injury to sanitation industry workers, healthcare staff, patients, and the public if they are not managed or collected, disposed of, and controlled properly (Yazdani et al., 2020). The management of healthcare wastes is controlled by factors including social, economic, technical, and environmental, which affect treatment techniques. The handling and management of healthcare wastes differ by country, but the most common disposal techniques include incineration, integrated steam sterilization systems, microwaves, autoclaves and steam retorts, plasma pyrolysis, promession, chemical disinfection systems, encapsulation, and landfilling (Manupati et al., 2021). Incineration is the least desirable of the previous methods because it is not sustainable and has many safety issues, whereas the best option is appropriate landfilling (Manupati et al., 2021).

Managing healthcare wastes has become one of the most serious problems faced by the global medical community during the COVID-19 pandemic (WHO, 2020a; Yu et al., 2020). This is due to the presence of a wide range of hazardous materials such as contaminated personal protective equipment, soiled dressings, used needles and syringes, heavy metals, body parts, diagnostic samples, pathogens,

Table 1 Selected recent studies on the management of various types of wastes

\begin{tabular}{|c|c|}
\hline General topic addressed & Reference(s) \\
\hline Agricultural wastes and their recycling & $\begin{array}{l}\text { De Corato (2020); Hsu (2020); Meng et al. (2020); Singh (2020); } \\
\text { Yuvaraj et al. (2021) }\end{array}$ \\
\hline Household waste disposal & Setiawan et al. (2019); Kumara and Pallegedara (2020); Uma et al. (2020) \\
\hline Industrial hazardous wastes for generation of energy & Ishaq and Dincer (2020) \\
\hline Industrial hazardous waste disposal & Fan et al. (2020) \\
\hline Medical wastes & $\begin{array}{l}\text { Chi et al. (2020); Kargar et al. (2020a, b); Peng et al. (2020); Sangkham } \\
\text { (2020); Taslimi et al. (2020); Wei et al. (2020) }\end{array}$ \\
\hline Healthcare waste disposal & Yazdani et al. (2020); Chauhan et al. (2021) \\
\hline $\begin{array}{l}\text { Disposal of healthcare waste generated during the } \\
\text { COVID-19 pandemic }\end{array}$ & Thakur (2020); Fan et al. (2021); Manupati et al. (2021); Yang et al. (2021) \\
\hline Face mask and medical waste disposal & Ilyas et al. (2020); Sangkham (2020); Jung et al. (2021) \\
\hline Nuclear waste disposal & Barton (2020); Xu et al. (2020); Small and Abrahamsen-Mills (2021) \\
\hline Radioactive waste disposal & $\begin{array}{l}\text { Bumbieler et al. (2021); Dyrcz et al. (2021); Gutiérrez-Rodrigo et al. (2021); } \\
\text { Kumar and Singh (2020); Perkoa and Martell (2021); Su et al. (2021); Walling } \\
\text { et al. (2021) }\end{array}$ \\
\hline Electronic waste disposal & $\begin{array}{l}\text { Islam et al. (2020); Li and Achal (2020); Shaikh et al. (2020); Zhou et al. } \\
\text { (2021) }\end{array}$ \\
\hline Municipal solid waste disposal & $\begin{array}{l}\text { Ferronato et al. (2020); Kulkarni (2020); Srivastava and Chakma (2020); Wong } \\
\text { et al. (2020); Penteado and de Castro (2021); Urban and Nakada (2021); } \\
\text { Michel Devadoss et al. (2021); Nanda and Berruti (2021) }\end{array}$ \\
\hline Plastic wastes & $\begin{array}{l}\text { Chaudhary et al. (2020); Jha and Kannan (2020a, b); Zhang et al. (2020a); } \\
\text { Abukhettala and Fall (2021); Liang et al. (2021); Shi et al. (2021); Vargas } \\
\text { and El Hanandeh (2021) }\end{array}$ \\
\hline Food wastes & $\begin{array}{l}\text { Ammann et al. (2020); Dou and Toth (2020); Jeswani et al. (2020); Brennan } \\
\text { et al. (2021); Huang et al. (2021) }\end{array}$ \\
\hline Construction waste disposal or concrete wastes & Biluca et al. (2020); Kong and Ma (2020); Davis et al. (2021) \\
\hline
\end{tabular}


toxic chemicals, blood, medical devices, pharmaceuticals, and radioactive materials in these healthcare wastes (Manupati et al., 2021; Yu et al., 2020). Therefore, several studies have been published on healthcare wastes and their relationship with COVID-19 in different countries (Table 2).
COVID-19 provided an urgent call for more interest in proper healthcare waste disposal techniques. During the COVID-19 pandemic, healthcare waste management became a serious problem that faces medical staff throughout the world (WHO, 2020b). COVID-19 is expected to cause a wide range of
Fig. 2 Various containers used by medical institutions for the disposal of hazardous healthcare wastes in Egypt (photos no. 1, 2, 3, and 4). Hazardous healthcare wastes that were disposed of without appropriate safety measures in piles of household garbage in Egypt (photos no. 5, 6, and 7)
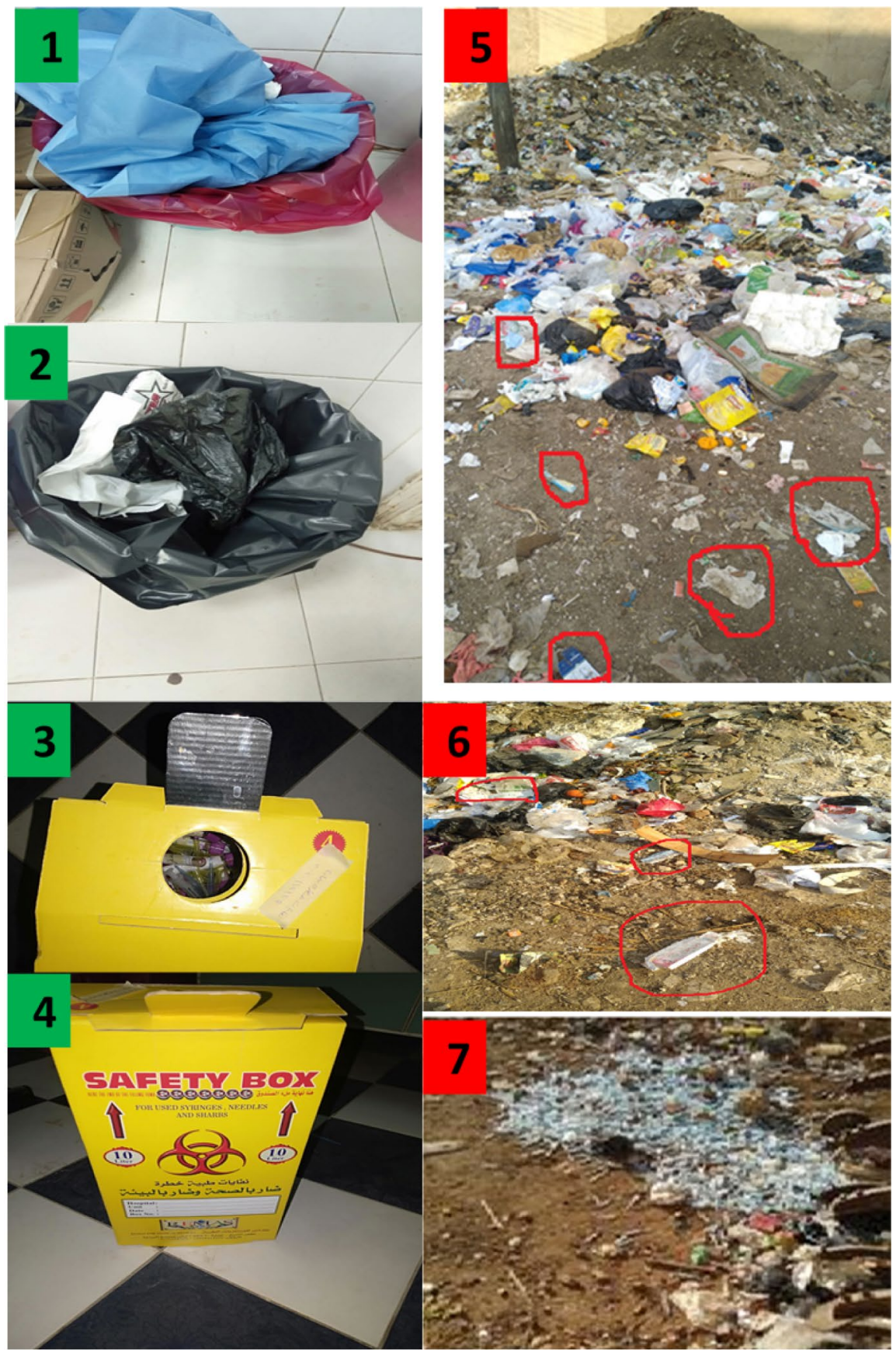
Table 2 A survey of some published literature considering medical waste disposal and COVID-19

\begin{tabular}{|c|c|c|}
\hline Country/region & The aim of the study or the most important findings of the study & Reference \\
\hline India & $\begin{array}{l}\text { Smart healthcare waste disposal systems could be developed using drivers elic- } \\
\text { ited from the circular economy and industry, particularly with the outbreak of } \\
\text { the COVID-19 pandemic across the world }\end{array}$ & Chauhan et al. (2021) \\
\hline $\begin{array}{l}\text { China, Czech } \\
\text { Republic, and } \\
\text { Singapore }\end{array}$ & $\begin{array}{l}\text { Global waste management has been influenced by COVID-19 through changes } \\
\text { in waste amount, timing, frequency, composition, safety and infection risks, } \\
\text { and its distribution based on location }\end{array}$ & Fan et al. (2021) \\
\hline India & $\begin{array}{l}\text { Incineration may be the worst method for healthcare waste disposal during and } \\
\text { after the COVID-19 pandemic and landfilling the best }\end{array}$ & Manupati et al. (2021) \\
\hline Brazil & $\begin{array}{l}\text { Effective municipal solid waste management during COVID-19 involves the } \\
\text { use of personal protective equipment, hygiene routines, and proper segrega- } \\
\text { tion, packing, and final destination of potentially contaminated wastes }\end{array}$ & Penteado and de Castro (2021) \\
\hline Global study & $\begin{array}{l}\text { Challenges and strategies are discussed for the effective management of plastic } \\
\text { wastes from masks and gloves during and after the COVID-19 pandemic }\end{array}$ & Vanapalli et al. (2021) \\
\hline China & $\begin{array}{l}\text { Great concern was expressed concerning security management for disposal } \\
\text { of healthcare wastes due to their high risk of being infectious during the } \\
\text { COVID-19 pandemic }\end{array}$ & Yang et al. (2021) \\
\hline Global study & $\begin{array}{l}\text { COVID-19 has generated huge amounts of hazardous wastes, for example, an } \\
\text { increase of about } 600 \% \text { in Hubei province, China }\end{array}$ & Haque et al. (2020) \\
\hline Global study & $\begin{array}{l}\text { Effective management of healthcare and bio-medical wastes requires appropri- } \\
\text { ate identification, collection, separation, storage, treatment, transportation, } \\
\text { and disposal, and is associated with disinfection }\end{array}$ & Klemeš et al. (2020) \\
\hline South Korea & $\begin{array}{l}\text { Discusses disinfection technologies (incineration, pyrolysis, microwave, dry } \\
\text { heat, vaporized hydrogen peroxide, and chemical options) and strategies for } \\
\text { COVID-19 hospital and bio-medical waste management }\end{array}$ & Ilyas et al. (2020) \\
\hline African countries & $\begin{array}{l}\text { Using personal protective equipment such as facemasks, medical gloves, and } \\
\text { aprons is recommended for essential service workers like doctors, nurses, } \\
\text { caregivers, and other people handling patients infected with COVID-19 }\end{array}$ & Nzediegwu and Chang (2020) \\
\hline Asian countries & $\begin{array}{l}\text { Discusses disposal management issues with face masks during the COVID-19 } \\
\text { pandemic in Asian countries. An increase in face masks and medical wastes } \\
\text { have been reported with increasing COVID-19 cases }\end{array}$ & Sangkham (2020) \\
\hline China & $\begin{array}{l}\text { The COVID-19 pandemic has generated enormous amounts of medical wastes. } \\
\text { Disposal management technologies include dry heat, autoclave steam, chemi- } \\
\text { cal disinfection, or microwave }\end{array}$ & Singh et al. (2020a) \\
\hline Global study & $\begin{array}{l}\text { The COVID-19 pandemic has changed the generation of global waste dynam- } \\
\text { ics, particularly plastic, bio-medical, and food wastes }\end{array}$ & Sharma et al. (2020) \\
\hline Iran & $\begin{array}{l}\text { Developed a fuzzy multi-trip location-routing model for medical waste man- } \\
\text { agement during the COVID-19 outbreak that is designed to minimize public } \\
\text { exposure to wastes during transport and disposal }\end{array}$ & Tirkolaee et al. (2021) \\
\hline India & $\begin{array}{l}\text { Proposed a sustainable healthcare waste management plan using a multi- } \\
\text { method approach (political, economic, social, technological, environmental, } \\
\text { and legal) to address the COVID-19 outbreak }\end{array}$ & Thakur (2020) \\
\hline Global study & $\begin{array}{l}\text { Generation, recycling, and disposal of medical wastes during the COVID-19 } \\
\text { pandemic have created many challenges to the prevention of virus transmis- } \\
\text { sion through solid wastes by ragpickers, sweepers, and healthcare staff }\end{array}$ & Tripathi et al. (2020) \\
\hline Global study & $\begin{array}{l}\text { The impact of landfilled COVID-19 medical wastes on soils and the potential } \\
\text { ability of soils to transmit COVID-19 need to be studied and understood }\end{array}$ & El-Ramady et al. (2020a) \\
\hline Iran & $\begin{array}{l}\text { Management of urban wastes, including medical, during the COVID-19 pan- } \\
\text { demic is an emerging challenge for developing countries that requires proper } \\
\text { disposal strategies }\end{array}$ & Zand and Heir (2020) \\
\hline
\end{tabular}


problems for humans and the broader environment because of its highly infectious properties. Different aspects of the environment, including surface and groundwater, beaches, wastewater, soils, and air quality, need to be protected (El-Ramady et al., 2020a; Lal et al., 2020; Zambrano-Monserrate et al., 2020). Proper waste management is very important to stop the spread of the pandemic. There is not enough research or data published regarding selection of the best healthcare waste disposal techniques to address this concern, but one important point of good healthcare waste management is to decrease environmental pollution (Ju et al., 2020).

In developing countries like Egypt, the COVID19 pandemic influenced air pollution, environmental noise, and medical and municipal solid wastes. The government of Egypt announced that the environmental noise level decreased by $75 \%$ during the lockdown period. On the other hand, healthcare solid waste dramatically increased from 70 to $300 \mathrm{Mg} \mathrm{day}^{-1}$ and recycling of the wastes was not efficient because the waste levels exceeded recycling capacity (Mostafa et al., 2021). The recycling process has been negatively affected both by the large amount of healthcare wastes, which may increase the rate of infection, and a decrease in available workers (Mostafa et al., 2021). The lockdown pushed people to eat more, leading to increased organic solid wastes. It also increased online shopping by $940 \%$ with a corresponding rise in related wastes. These wastes are now considered a serious problem because they may include waste from infected patients as well as protective equipment used by medical staff (Mostafa et al., 2021).

The USA stopped recycling in some regions to inhibit the spread of COVID-19 (Zambrano-Monserrate et al., 2020), while recycling proceeded even during lockdown in other countries like Egypt. However, the number of recycling workers available in Egypt was reduced by half after workers with chronic diseases were allowed to stay at home. This action negatively affected the efficiency of the recycling process as well as the quality of the final products. The same trend was seen in China, as Wuhan city produced around $50 \mathrm{Mg}$ of medical wastes day $^{-1}$ before the pandemic and had a corresponding waste disposal capacity of about $45 \mathrm{Mg} \mathrm{day}^{-1}$ (Wei, 2020). The generation of medical wastes by the city of Wuhan increased to nearly $247 \mathrm{Mg}$ day $^{-1}$ during the pandemic (Singh et al., 2020b). Challenges like this call for the use of large capacity mobile recycling facilities, particularly during the pandemic, which can be very important in allowing developing countries to process medical wastes when disposal facilities are limited. The mobile facilities are not only convenient for the current emergency situation but can also be used to provide strategic backup capacity for a state in the future as well (Singh et al., 2020a).

Global healthcare waste generation dramatically increased during the COVID-19 pandemic, by 30 to $50 \%$ as reported by the International Solid Waste Association, so the Egyptian government investigated around 1500 medical facilities to confirm proper waste management (Mostafa et al., 2021). The WHO suggested that the segregation process should continue as normal and COVID wastes should be treated as other healthcare wastes; the following specific instructions were offered for the disposal of COVID19 wastes (WHO, 2020b):

1. Separate the different types of waste products by the source of the wastes,

2. Use the same methods of disposal used for any other infectious healthcare wastes for COVID-19 waste,

3. Collect COVID-19 wastes in robust waste bins, which should have appropriately color-coded liners,

4. Collect all COVID-19 wastes at least once daily and transport them in sealed leakproof and puncture proof bins that display the biohazard label,

5. The space used for storage of COVID-19 wastes should be protected, sanitized, and safeguarded from pests and disease vectors,

6. Best healthcare waste management practices suggest that autoclaving or microwaving are the best non-incineration techniques for sanitizing COVID-19 waste,

7. All healthcare worker techniques must be regularly and properly tested and validated,

8. After sanitization, COVID-19 waste should be sent for recycling or disposal, and

9. If there are any substances that could not possibly be recycled, they should be destroyed.

Choosing the best healthcare waste disposal technique is a very complex decision as it depends on many criteria including the social, economic, and environmental dimensions of sustainability (Manupati et al., 2021). The disposal techniques used in most countries 
like China and Egypt were primarily based on a typical incineration plan, without any extra reserve or storage disposal capacity for additional healthcare wastes generated by the COVID-19 pandemic (Singh et al., 2020a). Incineration is no longer a preferred treatment technology in many places. Meeting modern atmospheric emission standards costs millions of dollars, the resulting ash must be treated as hazardous waste, and the ash continuously needs to be removed and buried. There are many lessons from this pandemic regarding waste disposal. We need to develop mobile disposal facilities that allow onsite emergency disposal of healthcare wastes; this will help locations where medical wastes are generated by providing emergency disposal options when local capability is overwhelmed. Parallel to this, it is very important to develop enough storage and reserve capacity to prevent medical wastes from piling up in inappropriate locations during emergency situations.

\section{Links between waste disposal and COVID-19}

COVID-19 has created serious impacts on all parts of our globe, and waste management is no exception. In developing countries, waste management is typically not conducted according to best practice guidelines (Tsukiji et al., 2020). During the pandemic, there was a drastic shift in the character of waste generated (Tripathi et al., 2020). There was a great increase in the amount of plastic waste associated with food/merchandise delivery as single-use plastic packs became preferred because they are recognized as being more sanitary (Patrício Silva et al., 2021). Plastic use for medical purposes also significantly increased (Fan et al., 2021; Mori et al., 2020; Tripathi et al., 2020).

Recently, organizations such as the World Health Organization (WHO), Centers for Disease Control and Prevention (CDC), International Solid Waste Association (ISWA), and Occupational Safety and Health Administration (OSHA) have provided guidelines for handling healthcare waste during the COVID-19 pandemic. The main point to all these guidelines is safety and protection of workers when collecting SARS-CoV-2-contaminated waste. These organizations classified COVID-19 waste into two types: (a) wastes generated in hospitals and health care services during treatment and (b) waste generated outside healthcare services due to social distancing and precautionary standards (such as masks and gloves). According to WHO and CDC, the second type of waste should be handled as a nonhazardous waste and can be transmitted to sanitary landfills (Somani et al., 2020). However, Oyedotun et al. (2020) mentioned that poor or ineffective waste management practices, such as open and inadequately managed landfills where both human and animal scavengers can roam freely and interact with waste that is probably contaminated, can spread the virus.

Thus, urban waste has and will continue to generate a huge volume of disposables (such as personal protective equipment (PPE) kits, surgical gloves, hand sanitizers, masks, and food packaging) as a part of daily life processes. There is a danger of COVID19 transmission through single-use plastics. Furthermore, common waste management practices could be disrupted as a result of safety matters and lockdowns. This implies that recyclable items may not be gathered and the establishment of a circular economy will be halted (Mori et al., 2020; Somani et al., 2020; Tripathi et al., 2020). This adds extra load to the landfills. In some cases, waste will reach drainage systems or water bodies, which increases the seriousness of water pollution (Fan et al., 2021; Mori et al., 2020; Tripathi et al., 2020), and may lead to viral transmission (El-Ramady et al., 2020b; Liu et al., 2020).

In addition, such contaminants intervene with natural habitats. The World-Wide Fund for Nature (WWF) has reported that about 10 million masks will be spread in the environment each month. If only $1 \%$ of these masks are not properly disposed of and each mask weights $4 \mathrm{~g}$, this means $40,000 \mathrm{~kg}$ of plastic will be introduced into the environment. Improper disposal of medical waste will also lead to soil, surface, and groundwater pollution and negatively affect biota (Tripathi et al., 2020). Avoiding such challenges requires appropriate handling and treatment procedures (Mori et al., 2020; Tsukiji et al., 2020).

Ecofriendly and sustainable waste management practices are common in developed countries, and thus, the established management structure helps reduce the threat of virus spread via increased generation of domestic waste. On the other hand, the poor and inadequate waste management plans in developing countries, where the waste is mainly disposed of in unsafe landfills and dumping grounds, leads to a higher risk of COVID-19 community spread (Oyedotun et al., 2020; Tripathi et al., 2020). 


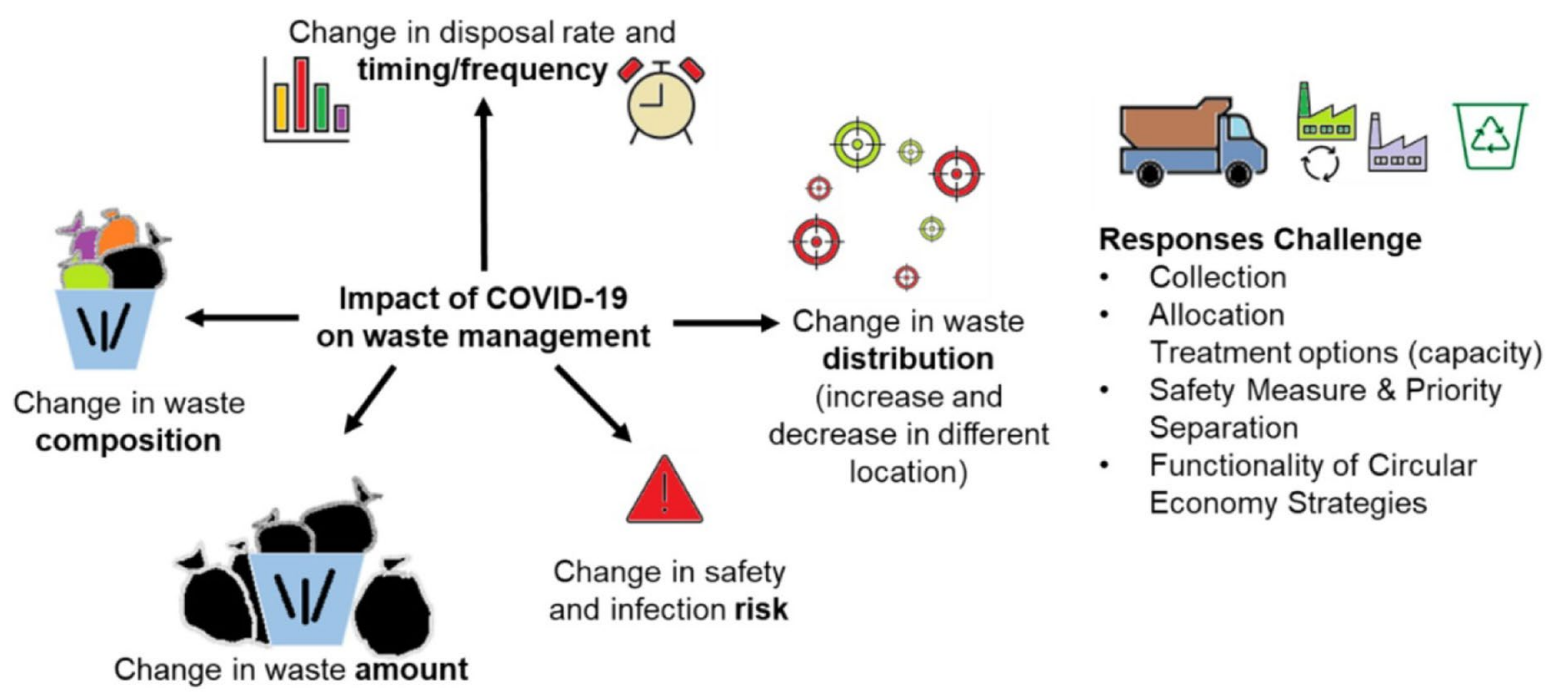

Fig. 3 COVID-19 impacts on waste management ( Source: Fan et al., 2021)

Fan et al. (2021) summarized COVID-19 impacts on waste management (Fig. 3). They reported that changes in waste amount, composition, disposal frequency, and temporal and spatial distribution affected infection risks. In addition, they emphasized that dynamic and responsive procedures are needed to face the extraordinary challenges presented. For instance, adjusting waste collection and allocation as a result of the shifts in waste composition and amount. Although the primary waste management strategies are mostly unexplored, they pose a great challenge as regards spreading SARS-CoV-2 with the increase in disposable PPE (Oyedotun et al., 2020).

\section{COVID-19 pandemic disposals in developing countries}

The COVID-19 crisis is a great threat not only for developing but also developed countries as regard human health, economic, social, and environmental issues. The main COVID-19 problem in developing counties is the limited medical support facilities and other health-related resources, especially under increasing cases, which leaves many people selftreating at home (Lucien et al., 2021; Mikhael \& AlJumaili, 2020; Zhang et al., 2020b). Therefore, the proper management of household medical wastes is one critical key to decrease or stop further spread of this virus and to avoid putting waste workers and others at risk. In 2020, the United Nations Development Programme (UNDP) started to support the health systems in vulnerable countries, including El Salvador, Bosnia and Herzegovina, Djibouti, Eritrea, Nigeria, Madagascar, Iran, China, Kyrgyzstan, Paraguay, Panama, Ukraine, Serbia, and Vietnam, in their fight against COVID-19 (UNDP, 2020).

Waste management has direct and/or indirect impacts that are linked to the spread of COVID-19 (Torkashvand et al., 2021). Therefore, guidelines have been developed for the management of wastes during this virus pandemic that include reducing the hours of waste workers during a shift, continuous daily assessment of disease symptoms in staff, and hand-washing and hand disinfection. Used, potentially contaminated waste should be transported in a covered truck using covered bins and the transporting equipment should be continuously washed and disinfected (Torkashvand et al., 2021). Any containers near healthcare centers should be managed as medical wastes, disposed of in dedicated sections of the landfill, and covered daily with soil (Torkashvand et al., 2021). Studies on the management of medical wastes and their disposal in developing countries during the COVID-19 pandemic have found the following: 
1. In some developing countries (e.g., Bangladesh), there is a lack of facilities needed for the disposal of medical wastes. Several clinics and hospitals burn medical wastes in their backyards or mix them with regular city wastes in bins that are not designated for biohazardous wastes (Haque et al., 2020; Shammi \& Tareq, 2020).

2. Standardization, guidelines, procedures, and strict management of face mask and medical wastes related to COVID-19 should be very carefully considered and followed to reduce risks in hospitals (Sangkham (2020)).

3. In developing countries, the management of different wastes is important to decrease the spread of COVID-19 by increasing scientific practices, perceptions, and potentials for research (Nzediegwu \& Chang, 2020; Oyedotun et al., 2020). New policy is needed to increase safety during and after the COVID-19 pandemic (Sharma et al., 2020; Tripathi et al., 2020).

4. There are emerging challenges in the management of urban wastes and how COVID-19 impacts this management (Sarkodie \& Owusu, 2020; Zand \& Heir, 2020, 2021). The increased release of plastics from face masks and other medically related sources has also caused enhanced marine pollution problems (Dharmaraj et al., 2021).

5. The COVID-19 pandemic created a sharp increase in the generation of heath care wastes. Stationary treatment facilities were superior to mobile facilities, but mobile facilities provided an ability to keep up with increasing waste loads (Yang et al., 2021).

Therefore, the effective management of COVID19 wastes is a great challenge for developing countries. The handling, treatment, and disposal of medical COVID-19 wastes need an integrated approach including both environmental and medical aspects.

\section{Conclusions}

Several types of wastes are generated as a result of human activities. These wastes need to be properly managed, particularly healthcare wastes, to avoid spreading COVID-19 as a result of exposures through these wastes. The struggle against COVID-19 starts with preventing viral spread in as many places as possible. Healthcare wastes that have been infected by COVID-19 patients may present a serious source of viral spread and outbreak. Therefore, the disposal of healthcare wastes needs to be done following best practices in waste handling and for sanitation worker protection. In this review, waste management challenges that have been documented by several developing countries were discussed, along with strategies for minimizing potential problems caused by waste. Developing countries suffer from inadequate national protocols that regulate handling healthcare wastes and their disposal, and disposal facilities are inadequate or absent for several hospitals in these countries. This situation has been exacerbated during the COVID-19 pandemic. Management of healthcare wastes should be conducted based on the health protocols and general guidelines of international health agencies. The unplanned environmental disposal of healthcare wastes may also represent a risk for biodiversity in different ecosystems (soil, water, and air) due to issues such as intensive microplastic pollution from disposable masks, gloves, and other medical supplies.

Acknowledgements The authors thank all staff members in the Soil and Water Dept., Faculty of Agriculture, Kafrelsheikh University, and the Soil Fertility and Plant Nutrition's Lab for their help and support for this work.

Author contribution This study was designed and implemented by all the authors, where all contributed to writing the manuscript, interpreting information presented, and have read and agreed to the final version of the manuscript.

\section{Declarations}

Ethics approval and consent to participate This article does not contain any studies with human participants or animals performed by any of the authors.

Consent for publication All authors declare their consent for publication.

Conflict of interest The authors declare no competing interests.

\section{References}

Abukhettala, M., \& Fall, M. (2021). Geotechnical characterization of plastic waste materials in pavement subgrade applications. Transportation Geotechnics, 27, 100472. https://doi.org/10.1016/j.trgeo.2020.100472 
Ammann, J., Osterwalder, O., Siegrist, M., Hartmann, C., \& Egolf, A. (2020). Comparison of two measures for assessing the volume of food waste in Swiss households. Resources, Conservation \& Recycling,. https://doi.org/ 10.1016/j.resconrec.2020.105295

Barton, N. (2020). A review of mechanical over-closure and thermal over-closure of rock joints: Potential consequences for coupled modelling of nuclear waste disposal and geothermal energy development. Tunnelling and Underground Space Technology, 99, 103379. https://doi. org/10.1016/j.tust.2020.103379

Biluca, J., de Aguiar, C. R., \& Trojan, F. (2020). Sorting of suitable areas for disposal of construction and demolition waste using GIS and ELECTRE TRI. Waste Management, 114, 307-320. https://doi.org/10.1016/j.wasman. 2020.07.007

Brennan, L., Langley, S., Verghese, K., Lockrey, S., Ryder, M., Francis, C., Phan-Le, N. T., \& Hill, A. (2021). The role of packaging in fighting food waste: A systematised review of consumer perceptions of packaging. Journal of Cleaner Production, 281, 125276. https://doi.org/10. 1016/j.jclepro.2020.125276

Bumbieler, F., Plúa, C., Tourchi, S., Vu, M.-N., Vaunat, J., Gens, A., \& Armand, G. (2021). Feasibility of constructing a full-scale radioactive high-level waste disposal cell and characterization of its thermo-hydro-mechanical behavior. International Journal of Rock Mechanics and Mining Sciences, 137, 104555. https://doi.org/10.1016/j. ijrmms.2020.104555

Chaudhary, S., Kumari, M., Chauhan, P., \& Chaudhary, G. R. (2020). Upcycling of plastic waste into fluorescent carbon dots: An environmentally viable transformation to biocompatible C-dots with potential prospective in analytical applications. Waste Management. https://doi.org/ 10.1016/j.wasman.2020.10.038

Chauhan, A., Jakhar, S. K., \& Chauhan, C. (2021). The interplay of circular economy with industry 4.0 enabled smart city drivers of healthcare waste disposal. Journal of Cleaner Production 279, 123854. https://doi.org/10. 1016/j.jclepro.2020.123854

Chi, T., Zhang, A., Zhang, X., Li, A.-D., Zhang, H., \& Zhao, Z. (2020). Characteristics of the antibiotic resistance genes in the soil of medical waste disposal sites. Science of the Total Environment, 730, 139042. https://doi.org/10. 1016/j.scitotenv.2020.139042

Davis, P., Aziz, F., Newaz, M. T., Sher, W., \& Simon, L. (2021). The classification of construction waste material using a deep convolutional neural network. Automation in Construction, 122, 103481. https://doi.org/10.1016/j. autcon.2020.103481

De Corato, U. (2020). Agricultural waste recycling in horticultural intensive farming systems by on-farm composting and compost-based tea application improves soil quality and plant health: A review under the perspective of a circular economy. Science of the Total Environment, 738, 139840. https://doi.org/10.1016/j.scitotenv.2020.139840

Dharmaraj, S., Ashokkumar, V., Hariharan, S., Manibharathi, A., Show, P. L., Tung, C. C., \& Ngamcharussrivichai, C. (2021). The COVID-19 pandemic face mask waste: A blooming threat to the marine environment. Chemosphere, 29601. https://doi.org/10.1016/j.chemosphere.2021.129601
Diaz, L. F., Savage, G. M., \& Eggerth, L. L. (2005). Alternatives for the treatment and disposal of healthcare wastes in developing countries. Waste Management, 25, 626-637. https://doi.org/10.1016/j.wasman.2005. 01.005

Dou, Z., \& Toth, J. D. (2020). Global primary data on consumer food waste: Rate and characteristics - A review. Resources, Conservation \& Recycling,. https://doi.org/ 10.1016/j.resconrec.2020.105332

Dyrcz, P., Frosio, T., Menaa, N., Magistris, M., \& Theis, C. (2021). Qualification of the activities measured by gamma spectrometry on unitary items of intermediatelevel radioactive waste from particle accelerators. Applied Radiation and Isotopes, 167, 109431. https://doi. org/10.1016/j.apradiso.2020.109431

Elbehiry, F., Elbasiouny, H., Ali, R., \& Brevik, E. C. (2020). Enhanced immobilization and phytoremediation of heavy metals in landfill contaminated soils. Water Air and Soil Pollution, 231, 204. https://doi.org/10.1007/ s11270-020-04493-2

El-Ramady, H., Brevik, E. C., Amer, M., Elsakhawy, T., Omara, A. E. D., Elbasiouny, H., Elbehiry, F., Mosa, A. A., El-Ghamry, A. M., Bayoumi, Y., \& Shalaby, T. A. (2020a). Soil and air pollution in the era of COVID19: A global issue. Egyptian Journal of Soil Science 60, 437-448. https://doi.org/10.21608/ejss.2020.49996.1411

El-Ramady, H., Eid, Y., \& Brevik, E. C. (2020b). New pollution challenges in groundwater and wastewater due to COVID-19. Journal of Sustainable Agricultural Sciences 46, 61-73. https://doi.org/10.21608/jsas.2020.51353. 1257

Fan, G., Zhang, M., Peng, W., Zhou, G., Deng, L., Chang, L., Cao, Y., \& Li, P. (2020). Clean products from coal gasification waste by flotation using waste engine oil as collector: Synergetic cleaner disposal of wastes. Journal of Cleaner Production. https://doi.org/10.1016/j.jclepro. 2020.124943

Fan, Y. V., Jiang, P., Hemzal, M., \& Klemeš, J. J. (2021). An update of COVID-19 influence on waste management. Science of the Total Environment, 754, 142014. https:// doi.org/10.1016/j.scitotenv.2020.142014

Ferronato, N., Alarcon, G. P. P., Lizarazu, E. G. G., \& Torretta, V. (2020). Assessment of municipal solid waste collection in Bolivia: Perspectives for avoiding uncontrolled disposal and boosting waste recycling options. Resources, Conservation \& Recycling,. https://doi.org/ 10.1016/j.resconrec.2020.105234

Ferronato, N., \& Torretta, V. (2019). Waste mismanagement in developing countries: A review of global issues. International Journal of Environmental Research and Public Health, 16(6), 1060. https://doi.org/10.3390/ijerph16061060

Gutiérrez-Rodrigo, V., Martín, P. L., \& Villar, M. V. (2021). Effect of interfaces on gas breaktrough pressure in compacted bentonite used as engineered barrier for radioactive waste disposal. Process Safety and Environmental Protection, 149, 244-257. https://doi.org/10.1016/j.psep.2020.10.053

Haque, M. S., Uddin, S., Sayem, S. M., \& Mohib, K. M. (2020). Coronavirus disease 2019 (COVID-19) induced waste scenario: A short overview. Journal of Environmental Chemical Engineering. https://doi.org/10.1016/j. jece. 2020.104660 
Hsu, E. (2020). Cost-benefit analysis for recycling of agricultural wastes in Taiwan. Waste Management. https://doi. org/10.1016/j.wasman.2020.09.051

Huang, I. Y., Manning, L., James, K. L., Grigoriadis, V., Millington, A., Wood, V., \& Ward, S. (2021). Food waste management: A review of retailers' business practices and their implications for sustainable value. Journal of Cleaner Production, 285, 125484. https://doi.org/10. 1016/j.jclepro.2020.125484

Ilyas, S., Srivastava, R. R., \& Kim, H. (2020). Disinfection technology and strategies for COVID-19 hospital and bio-medical waste management. Science of the Total Environment, 749, 141652. https://doi.org/10.1016/j.scitotenv.2020.141652

Ishaq, H., \& Dincer, I. (2020). A new approach in treating industrial hazardous wastes for energy generation and thermochemical hydrogen production. Journal of Cleaner Production, 125303. https://doi.org/10.1016/j.jclepro. 2020.125303

Islam, M. T., Dias, P., \& Huda, N. (2020). Young consumers' e-waste awareness, consumption, disposal, and recycling behavior: A case study of university students in Sydney, Australia. Journal of Cleaner Production. https://doi.org/ 10.1016/j.jclepro.2020.124490

Jeswani, H. K., Figueroa-Torres, G., \& Azapagic, A. (2020). The extent of food waste generation in the UK and its environmental impacts. Sustainable Production and Consumption. https://doi.org/10.1016/j.spc.2020.12.021

Jha, K. K., \& Kannan, T. T. M. (2020a). Recycling of plastic waste into fuel by pyrolysis - A review. Proceedings. https://doi.org/10.1016/j.matpr.2020.10.181

Jha, K. K., \& Kannan, T. T. M. (2020b). Alternate fuel preparation in low cost from waste plastic: A review. Materials Today: Proceedings. https://doi.org/10.1016/j.matpr. 2020.09.80

Ju, Y., Liang, Y., Luis, M., Gonzalez, E. D. S., Giannakis, M., Dong, P., \& Wang, A. (2020). A new framework for healthcare waste disposal alternative selection under multi-granular linguistic distribution assessment environment. Computers \& industrial engineering, 145, 106489.

Jung, S., Lee, S., Dou, X., \& Kwon, E. E. (2021). Valorization of disposable COVID-19 mask through the thermochemical process. Chemical Engineering Journal, 405, 126658. https://doi.org/10.1016/j.cej.2020.126658

Kargar, S., Paydar, M. M., \& Safaei, A. S. (2020a). A reverse supply chain for medical waste: A case study in Babol healthcare sector. Waste Management, 113, 197-209. https://doi.org/10.1016/j.wasman.2020.05.052

Kargar, S., Pourmehdi, M., \& Paydar, M. M. (2020b). Reverse logistics network design for medical waste management in the epidemic outbreak of the novel coronavirus (COVID-19). Science of the Total Environment, 746, 141183. https://doi.org/10.1016/j.scitotenv.2020.141183

Klemeš, J. J., Fan, Y. V., Tan, R. R., \& Jiang, P. (2020). Minimising the present and future plastic waste, energy and environmental footprints related to COVID-19. Renewable and Sustainable Energy Reviews, 127, 109883. https://doi.org/10.1016/j.rser.2020.109883

Kong, L., \& Ma, B. (2020). Evaluation of environmental impact of construction waste disposal based on fuzzy set analysis. Environmental Technology \& Innovation, 19, 100877. https://doi.org/10.1016/j.eti.2020.100877
Kulkarni, B. N. (2020). Environmental sustainability assessment of land disposal of municipal solid waste generated in Indian cities - A review. Environmental Development, 33, 100490. https://doi.org/10.1016/j.envdev.2019. 100490

Kumar, R., \& Singh, R. (2020). Thermoplastic containers for disposal of radioactive waste. In: Encyclopedia of Materials: Plastics and Polymers. https://doi.org/10.1016/ B978-0-12-820352-1.00007-9

Kumara, A. S., \& Pallegedara, A. (2020). Household waste disposal mechanisms in Sri Lanka: Nation-wide survey evidence for their trends and determinants. Waste Management, 114, 62-71. https://doi.org/10.1016/j.wasman. 2020.06.028

Lal, R., Brevik, E. C., Dawson, L., Field, D., Glaser, B., Hartemink, A. E., Hatano, R., Lascelles, B., Monger, M., Scholten, T., Singh, B. R., Spiegel, H., Terribile, F., Basile, A., Zhang, Y., Horn, R., Kosaki, T., \& Sánchez, L. B. R. (2020). Managing soils for recovering from the COVID-19 pandemic. Soil Systems, 4, 46. https://doi.org/ 10.3390/soilsystems4030046

Li, W., \& Achal, V. (2020). Environmental and health impacts due to e-waste disposal in China - A review. Science of the Total Environment, 737, 139745. https://doi.org/10.1016/j. scitotenv.2020.139745

Liang, Y., Tan, Q., Song, Q., \& Li, J. (2021). An analysis of the plastic waste trade and management in Asia. Waste Management, 119, 242-253. https://doi.org/10.1016/j. wasman.2020.09.049

Liu, D., Thompson, J. R., Carducci, A., \& Bi, X. (2020). Potential secondary transmission of SARS-CoV-2 via wastewater. Science of the Total Environment, 749, 142358. https://doi.org/10.1016/j.scitotenv.2020.142358

Lucien, M. A. B., Canarie, M. F., Kilgore, P. B., Jean-Denis, G., Fénélon, N., Pierre, M., Cerpa, M., Joseph, G. A., Maki, G., Zervos, M. J., Dely, P., Boncy, J., Sati, H., del Rio, A., \& Ramon-Pardo, P. (2021). Antibiotics and antimicrobial resistance in the COVID-19 era: Perspective from resource-limited settings. International Journal of Infectious Diseases, 104, 250-254. https://doi.org/10. 1016/j.ijid.2020.12.087

Ma, Y., Stubbings, W. A., Cline-Cole, R., \& Harrad, S. (2021). Human exposure to halogenated and organophosphate flame retardants through informal e-waste handling activities - A critical review. Environmental Pollution, 268, 115727. https://doi.org/10.1016/j.envpol.2020.115727

Manupati, V. K., Ramkumar, M., Baba, V., \& Agarwal, A. (2021). Selection of the best healthcare waste disposal techniques during and post COVID-19 pandemic era. Journal of Cleaner Production, 281, 125175. https://doi. org/10.1016/j.jclepro.2020.125175

Meng, L., Jin, K., Yi, R., Chen, M., Peng, J., \& Pan, Y. (2020). Enhancement of bioenergy recovery from agricultural wastes through recycling of cellulosic alcoholic fermentation vinasse for anaerobic co-digestion. Bioresource Technology, 311, 123511. https://doi.org/10.1016/j.biortech.2020.123511

Michel Devadoss, P. S., Agamuthu, P., Mehran, S. B., Santha, C., \& Fauziah, S. H. (2021). Implications of municipal solid waste management on greenhouse gas emissions in Malaysia and the way forward. Waste Management, 119, 135-144. https://doi.org/10.1016/j.wasman.2020.09.038 
Mikhael, E. M., \& Al-Jumaili, A. A. (2020). Can developing countries face novel coronavirus outbreak alone? The Iraqi situation. Public Health in Practice, 1, 100004. https://doi.org/10.1016/j.puhip.2020.100004

Mori, H., Takahashi, Y., Zusman, E., Mader, A., Kawazu, E., Otsuka, T., \& Takai, E. (2020). Implications of COVID19 for the environment and sustainability. Institute for Global Environmental Strategies. https://www.jstor.org/ stable/resrep24951

Mostafa, M. K., Gamal, G., \& Wafiq, A. (2021). The impact of COVID 19 on air pollution levels and other environmental indicators - A case study of Egypt. Journal of Environmental Management, 277, 111496. https://doi.org/10. 1016/j.jenvman.2020.111496

Nanda, S., \& Berruti, F. (2021). A technical review of bioenergy and resource recovery from municipal solid waste. Journal of Hazardous Materials, 403, 123970. https:// doi.org/10.1016/j.jhazmat.2020.123970

Nzediegwu, C., \& Chang, S. X. (2020). Improper solid waste management increases potential for COVID-19 spread in developing countries. Resources, Conservation \& Recycling, 161, 104947. https://doi.org/10.1016/j.resconrec. 2020.104947

Oyedotun, T. D. T., Kasim, O. F., Famewo, A., Oyedotun, T. D., Moonsammy, S., Ally, N., \& Renn-Moonsammy, D.-M. (2020). Municipal waste management in the era of COVID-19: Perceptions, practices, and potentials for research in developing countries. Research in Globalization, 2, 100033. https://doi.org/10.1016/j.resglo.2020. 100033

Pandey, D., Verma, S., Verma, P., Mahanty, B., Dutta, K., Daverey, A., \& Arunachalam, K. (2021). SARS-CoV-2 in wastewater: Challenges for developing countries. International Journal of Hygiene and Environmental Health, 231, 113634. https://doi.org/10.1016/j.ijheh.2020.113634

Patrício Silva, A. L., Prata, J. C., Walker, T. R., Duarte, A. C., Ouyang, W., Barcelò, D., \& Rocha-Santos, T. (2021). Increased plastic pollution due to COVID-19 pandemic: Challenges and recommendations. Chemical Engineering Journal, 405, 126683. https://doi.org/10.1016/j.cej.2020.126683

Peng, J. M. M., Wu, X., Wang, R. M. M., Li, C. M. M., Zhang, Q. B. M., \& Wei, D. M. D. (2020). Medical waste management practice during the 2019-2020 novel coronavirus pandemic: Experience in a general hospital. American Journal of Infection Control, 48, 918-921. https://doi.org/10.1016/j. ajic.2020.05.035

Penteado, C. S. G., \& de Castro, M. A. S. (2021). Covid-19 effects on municipal solid waste management: What can effectively be done in the Brazilian scenario? Resources. Conservation \& Recycling, 164, 105152. https://doi.org/ 10.1016/j.resconrec.2020.105152

Perkoa, T., Martell, M. (2021). Communication and stakeholder engagement of microbiology in radioactive waste disposal. In: Jonathan R. Lloyd and Andrea Cherkouk (Eds.), The Microbiology of Nuclear Waste Disposal. https://doi.org/10.1016/B978-0-12-818695-4. 00013-7, pp: 291 - 320. Elsevier Inc.

Sangkham, S. (2020). Face mask and medical waste disposal during the novel COVID-19 pandemic in Asia. Case Studies in Chemical and Environmental Engineering, 2, 100052. https://doi.org/10.1016/j.cscee.2020.100052
Sarkodie, S. A., \& Owusu, P. A. (2020). Impact of COVID-19 pandemic on waste management. Environment, Development and Sustainability. https://doi.org/10.1007/ s10668-020-00956-y

Setiawan, R. P., Kaneko, S., \& Kawata, K. (2019). Impacts of pecuniary and non-pecuniary information on proenvironmental behavior: A household waste collection and disposal program in Surabaya city. Waste Management, 89, 322-335. https://doi.org/10.1016/j.wasman.2019.04.015

Shaikh, S., Thomas, K., \& Zuhair, S. (2020). An exploratory study of e-waste creation and disposal: Upstream considerations. Resources, Conservation \& Recycling, 155, 104662. https:// doi.org/10.1016/j.resconrec.2019.104662

Shammi, M., \& Tareq, S. M. (2020). Environmental catastrophe of COVID-19: Disposal and management of PPE in Bangladesh. Global Social Welfare. https://doi.org/10. 1007/s40609-020-00195-z

Sharma, H. B., Vanapalli, K. R., Cheela, V. S., Ranjan, V. P., Jaglan, A. K., Dubey, B., Goel, S., \& Bhattacharya, J. (2020). Challenges, opportunities, and innovations for effective solid waste management during and post COVID-19 pandemic. Resources, Conservation \& Recycling, 162, 105052. https://doi.org/10.1016/j.resconrec. 2020.105052

Shi, J., Zhang, C., \& Chen, W.-Q. (2021). The expansion and shrinkage of the international trade network of plastic wastes affected by China's waste management policies. Sustainable Production and Consumption, 25, 187-197. https://doi.org/10.1016/j.spc.2020.08.005

Singh, N., Tang, Y., \& Ogunseitan, O. A. (2020b). Environmentally sustainable management of used personal protective equipment. Environmental Science \& Technology. https://doi.org/10.1021/acs.est.0c03022

Singh, N., Tang, Y., Zhang, Z., \& Zheng, C. (2020a). COVID19 waste management: Effective and successful measures in Wuhan, China. Resources, Conservation \& Recycling, 163, 105071. https://doi.org/10.1016/j.resconrec.2020. 105071

Singh, R. (2020). Recycling of agricultural waste for wastewater treatment. In: Saleem Hashmi and Imtiaz Ahmed Choudhury (Eds.), Encyclopedia of Renewable and Sustainable Materials, Volume 2. https://doi.org/10.1016/ B978-0-12-803581-8.11444-4, pp: $514-519$.

Small, J. S., \& Abrahamsen-Mills, L. (2021). Modeling of microbial processes to support the safety case for nuclear waste disposal. In: Jonathan R. Lloyd and Andrea Cherkouk (Eds.), The Microbiology of Nuclear Waste Disposal. https://doi.org/10.1016/B978-0-12-818695-4. 00012-5267. Elsevier Inc. pp: 267-289.

Somani, M., Srivastava, A. N., Gummadivalli, S. K., \& Sharma, A. (2020). Indirect implications of COVID-19 towards sustainable environment: An investigation in Indian context. Bioresource Technology Reports, 11, 100491. https://doi.org/10.1016/j.biteb.2020.100491

Srivastava, A. N., \& Chakma, S. (2020). Heavy metals speciation study revealing merits of anaerobic co-disposal of municipal solid waste with discrete paper mill sludges: An experimental investigation in simulated landfill bioreactors. Journal of Environmental Chemical Engineering, 8, 104337. https://doi.org/10.1016/j.jece.2020. 104337 
Steffan, J. J., Brevik, E. C., Burgess, L. C., \& Cerdà, A. (2018). The effect of soil on human health: An overview. European Journal of Soil Science, 69, 159-171. https://doi.org/10.1111/ejss.12451

Su, J., Gao, Y., Ni, S., Xu, R., \& Sun, X. (2021). A safer and cleaner process for recovering thorium and rare earth elements from radioactive waste residue. Journal of Hazardous Materials, 406, 124654. https://doi.org/10. 1016/j.jhazmat.2020.124654

Taslimi, M., Batta, R., \& Kwon, C. (2020). Medical waste collection considering transportation and storage risk. Computers and Operations Research, 120, 104966. https:// doi.org/10.1016/j.cor.2020.104966

Thakur, D. V. (2020). Framework for PESTEL dimensions of sustainable healthcare waste management: Learnings from COVID-19 outbreak. Journal of Cleaner Production. https://doi.org/10.1016/j.jclepro.2020.125562

Tirkolaee, E. B., Abbasian, P., \& Weber, G.-W. (2021). Sustainable fuzzy multi-trip location-routing problem for medical waste management during the COVID-19 outbreak. Science of the Total Environment, 756, 143607. https:// doi.org/10.1016/j.scitotenv.2020.143607

Torkashvand, J., Jafari, A. J., Godini, K., Kazemi, Z., Kazemi, Z., \& Farzadkia, M. (2021). Municipal solid waste management during COVID-19 pandemic: A comparison between the current activities and guidelines. Journal of Environmental Health Science and Engineering. https:// doi.org/10.1007/s40201-020-00591-9

Tripathi, A., Tyagi, V. K., Vivekanand, V., Bose, P., \& Suthar, S. (2020). Challenges, opportunities and progress in solid waste management during COVID-19 pandemic. Case Studies in Chemical and Environmental Engineering, 2, 100060. https://doi.org/10.1016/j.cscee.2020.100060

Tsukiji, M., Gamaralalage, P. J. D., Pratomo, I. S. Y. , Onogawa, K., Alverson, K., Honda, S., Ternald, D., Dilley, M., Fujioka, J., \& Condrorini, D. (2020). Waste management during the COVID-19 pandemic from response to recovery. United Nations Environment Programme, International Environmental Technology Centre (IETC) IGES Center Collaborating with UNDP on Environmental Technologies (CCET).

Uma, K. E., Nwaka, I. D., Nwogu, M. U., \& Obidike, P. C. (2020). What are the triggers of household decisionmaking on waste disposal choices? A Gander Differentiated Analysis. Heliyon, 6, e05588. https://doi.org/10. 1016/j.heliyon.2020.e05588

UNDP. (2020). COVID-19: Looming crisis in developing countries threatens to devastate economies and ramp up inequality. Accessed on 16 Jan 2021 from the following link: https:// www.undp.org/content/brussels/en/home/presscenter/ pressreleases/covid-19--looming-crisis-in-developingcountries-threatens-to-de.html

Urban, R. C., \& Nakada, L. Y. K. (2021). COVID-19 pandemic: Solid waste and environmental impacts in Brazil. Science of the Total Environment, 755, 142471. https://doi.org/10. 1016/j.scitotenv.2020.142471

Vanapalli, K. R., Sharma, H. B., Ranjan, V. P., Samal, B., Bhattacharya, J., Dubey, B. K., \& Goel, S. (2021). Challenges and strategies for effective plastic waste management during and post COVID-19 pandemic.
Science of the Total Environment, 750, 141514. https:// doi.org/10.1016/j.scitotenv.2020.141514

Vargas, C., \& El Hanandeh, A. (2021). Systematic literature review, meta-analysis and artificial neural network modelling of plastic waste addition to bitumen. Journal of Cleaner Production, 280, 124369. https://doi.org/10. 1016/j.jclepro.2020.124369

Walling, S. A., Kauffmann, M. N., Gardner, L. J., Bailey, D. J., Stennett, M. C., Corkhill, C. L., \& Hyatt, N. C. (2021). Characterisation and disposability assessment of multi-waste stream in-container vitrified products for higher activity radioactive waste. Journal of Hazardous Materials, 401, 123764. https://doi.org/10. 1016/j.jhazmat.2020.123764

Wang, Q., Su, M. (2020). A preliminary assessment of the impact of COVID-19 on environment - A case study of China. The Science of the total environment, 728, 138915. https://doi.org/10.1016/j.scitotenv.2020.138915

Wei, G. (2020). Medical waste management experience and lessons in covid-19 outbreak in Wuhan. Accessed from this link on 16 Jan 2021, https://www.waste360.com/ medical-waste/medical-waste-management-experienceand-lessons-covid-19-outbreak-wuhan

Wei, Y., Cui, M., Ye, Z., \& Guo, Q. (2020). Environmental challenges from the increasing medical waste since SARS outbreak. Journal of Clean Product. https://doi. org/10.1016/j.jclepro.2020.125246.

WHO. (2020a). Water, sanitation, hygiene and waste management for COVID-19: Technical brief, 03 March 2020 (No. WHO/2019-NcOV/IPC_ WASH/2020.1).

WHO. (2020b). Rational use of personal protective equipment (PPE) for coronavirus disease (COVID-19): interim guidance, 19 March 2020.

WHO. (2021). WHO coronavirus disease (COVID-19) dashboard. https://covid19.who.int/. Accessed 21 Jun 2021.

Wong, G., Gan, M., Fan, X., Ji, Z., Chen, X., \& Wang, Z. (2020). Co-disposal of municipal solid waste incineration fly ash and bottom slag: A novel method of low temperature melting treatment. Journal of Hazardous Materials. https://doi.org/10.1016/j.jhazmat.2020.124438

Wu, C.-Y., Hu, M.-C., \& Ni, F.-C. (2021). Supporting a circular economy: Insights from Taiwan's plastic waste sector and lessons for developing countries. Sustainable Production and Consumption, 26, 228-238. https:// doi.org/10.1016/j.spc.2020.10.009

Xu, H., Rutqvist, J., \& Birkholzer, J. (2020). A study of thermal pressurization and potential for hydro-fracturing associated with nuclear waste disposal in argillaceous claystone. International Journal of Rock Mechanics and Mining Sciences, 136, 104536. https://doi.org/10. 1016/j.ijrmms.2020.104536

Yang, L., Yu, X., Wu, X., Wang, J., Yan, X., Jiang, S., \& Chen, Z. (2021). Emergency response to the explosive growth of health care wastes during COVID-19 pandemic in Wuhan, China. Resources, Conservation \& Recycling 164, 105074.

Yazdani, M., Tavana, M., Pamučar, D., \& Chatterjee, P. (2020). A rough based multi-criteria evaluation method for healthcare waste disposal location decisions. Computers \& Industrial Engineering, 143, 106394. https:// doi.org/10.1016/j.cie.2020.106394 
Yu, H., Sun, X., Solvang, W. D., \& Zhao, X. (2020). Reverse logistics network design for effective management of medical waste in epidemic outbreaks: Insights from the coronavirus disease 2019 (COVID-19) outbreak in Wuhan (China). International Journal of Environmental Research in Public Health, 17(5), 1770.

Yuvaraj, A., Thangaraj, R., Ravindran, B., Chang, S. W., \& Karmegam, N. (2021). Centrality of cattle solid wastes in vermicomposting technology e A cleaner resource recovery and biowaste recycling option for agricultural and environmental sustainability. Environmental Pollution, 268, 115688. https://doi.org/10.1016/j.envpol. 2020.115688

Zambrano-Monserrate, M. A., Ruanob, M. A., \& SanchezAlcalde, L. (2020). Indirect effects of COVID-19 on the environment. Science of the Total Environment, 728, 138813. https://doi.org/10.1016/j.scitotenv.2020. 138813

Zand, A. D., \& Heir, A. V. (2020). Emerging challenges in urban waste management in Tehran, Iran during the COVID-19 pandemic. Resources, Conservation \& Recycling, 162, 105051. https://doi.org/10.1016/j.resconrec. 2020.105051

Zand, A. D., \& Heir, A. V. (2021). Environmental impacts of new Coronavirus outbreak in Iran with an emphasis on waste management sector. Journal of Material Cycles and Waste Management, 23, 240-247. https://doi.org/ 10.1007/s10163-020-01123-1

Zhang, F., Zhao, Y., Wang, D., Yan, M., Zhang, J., Zhang, P., Ding, T., Chen, L., \& Chen, C. (2020a). Current technologies for plastic waste treatment: A review. Journal of Cleaner Production. https://doi.org/10.1016/j. jclepro.2020.124523

Zhang, J., Lu, X., Jin, Y., \& Zheng, Z.-J. (2020b). Hospitals' responsibility in response to the threat of infectious disease outbreak in the context of the coronavirus disease 2019 (COVID-19) pandemic: Implications for lowand middle-income countries. Global Health Journal. https://doi.org/10.1016/j.glohj.2020.11.005

Zhou, Y., Sun, J., Wang, L., Zhu, G., Li, M., Liu, J., Li, Z., Gong, H., Wu, C., \& Yin, G. (2021). Multiple classes of chemical contaminants in soil from an e-waste disposal site in China: Occurrence and spatial distribution. Science of the Total Environment, 752, 141924. https://doi.org/10.1016/j.scitotenv.2020.141924

Publisher's Note Springer Nature remains neutral with regard to jurisdictional claims in published maps and institutional affiliations. 